\section{MAN OF NEANDERTHAL TYPE IN THE CAMBRIDGE FENS.}

THE bones of primæval rian are so rare, and there is so much uncertainty as to the mode of occurrence and association of the earlier specimens, that it is important to place on record any new case which may be brought under our notice. I have had the good fortune lately to assist in digging out the skeleton of a man whose skull was distinctly of Neanderthal type. In this case I think I am justified in using that name, because as much as was preserved of the Neanderthal man is represented in the skull now described, and is similar to it.

We cannot compare the Neanderthal man, whose lower jaw was lost, with the man of Mauer, near Heidelberg, of whom only the lower jaw has been preserved. But we have the lower jaw of the man found near Shippea Hill in the Cambridge Fens, and it differs in essential characters from that of Mauer. The skull of the Shippea man differs also in form from those of Sainte Chapelle, described by M. Marcellin Boule. The general section across the ground is as shown in Fig. I. An island of Kimeridge Clay, known as Shippea Hill, rises out of the fen about 3 miles E.S.E. of Littleport, and on it a farm represents the site, and preserves some of the ancient masonry, of a monastic retreat connected with Ely.

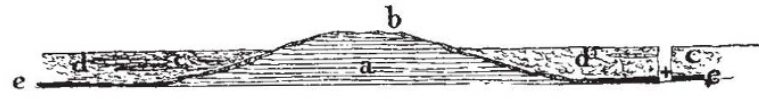

Fig. I.--Shippea Hill. $a$, Kimeridge clay; $b$, gravel; $c$, peat; $d$, white marl; $e$, Buttery clay; + , position of skeleton.

On the Littleport side the peat, with beds of white marl in it, rests at a depth of from 4 to 6 feet on a blue-grey fine unctuous clay, which we refer to as the Buttery Clay. This contains large shells of the common cockle with valves adherent, Tellina (Tacoma) balthica, Scrobicularia piperata, and other estuarine shells, and, in the peat above it, bones of the Urus, wild boar, and beaver have been found.

On the south side of Shippea Hill the section is much the same, but here we have not, so far, found the estuarine shells in the Buttery Clay. Freshwater shells occur commonly in the white marl and less commonly in the peat.

The skeleton was found in digging trenches through the peat in order to obtain the underlying clay to lay on the land, so that a clean cut was made down to the Buttery Clay in each trench.

Mr. Luddington, to whom the property belongs, and Mrs. Luddington, who has a collection of objects from the fens, informed us of the discovery, and gave us every facility for investigating the circumstances on the spot at once. We were thus able to examine the section and collect a large number of the fragments of the skull and other bones of the skeleton which had been overlooked at first.

The skeleton was found between Shippea Hill
Farm and the railway, about 4 feet down in the peat, and a few inches above the Buttery Clay. It was bunched up so that all the bones were packed into a space not more than two feet square. It looked as if the man had been mired and sunk straight down exhausted, and not as if a dead body had been cairried down by water. The character of the peat also precludes this supposition, for it is peat grown on the spot, and not travelled peat, though in that often-flooded area it readily becomes sludge, and penetrates into any cavity. I lay stress upon this point because I know from my own experience in excavations that there are sources of error in speculations as to the original form of fossil skulls.

If a sepulchral urn has not been tightly filled before interment, and the interior is capable of compression, it is commonly crushed, or, if not well fired, squeezed out of shape, without much fracture, and on drying retains its flattened form. Skulls also, if buried under conditions which do not allow of their being filled pari passu with the disappearance of the organic matter inside, are sometimes, of course, crushed flat, but sometimes only deformed by the pressure, and, when dried, appear to be of abnormal shape. In the example now described, however, the peat filled the skull and preserved its form against the small pressure of the overlying spongy material. Unfortunately it got broken in the first excavation, but the fragments were not deformed, and readily fell into their place in the rotundity of the cranium. It has now been skilfully restored by Mr. C. E. Gray, and I hope on a future occasion to be able to offer a full description of it by an expert.

I will only point out now that it is a good round skull, somewhat largely developed posteriorly, but not elongated into a conical projection in the occipital region. It agrees very well in its norma verticalis with the' Neanderthal skull. (See Fig. 2.)

The most conspicuous feature is the prominent brow, its strong supraciliary ridges and flattened forehead bringing it again into comparison with the Neanderthal skull. (See Fig. 3, side view, and Fig. 4, front view.)

There is very little of the face or upper jaw preserved. The lower jaw of the Neanderthal man is missing; so here our comparison with that example ends. In the Shippea Hill man the lower jaw (see Fig. 5) ${ }^{1}$ is well preserved. It does not show the flat or receding chin of the Mauer jaw or of some of those recently described by $M$. Marcellin Boule. The teeth are large, strong, and sound, but curiously worn down obliquely on the outer margin, as if the upper jaw had been somewhat broader than the lower.

Here, therefore, is a man whose skull shows all the characteristies of that of Neanderthal, including the prominent supraciliary ridges, but having in addition a powerful lower jaw, and large terminations to his limb bones, and found undoubtedly in the peat of the fens.

1 The drawings Figs, $x$ to 5 are by the skilful and experienced pencil of Mr. Edwin Wilson.

NO. 22 I 4 , VOL. 89] 
I reserve discussion of the possibility of this part of the peat being of more ancient date than that to which it has generally been referred--an opinion which might be suggested by the occurrence of Rhinoceros tichorhinus under the peat at Little Downham, or of the still older Elephas antiquus under the margin of the fen deposits near Whittlesea, and will content myself now with stating my own conviction that the peat in which the Shippea man was found cannot be older than Neolithic times, and may be much newer.

Notwithstanding his Neanderthal character I should not be surprised to find that he was a man of much later date, even a monk from Ely, per-
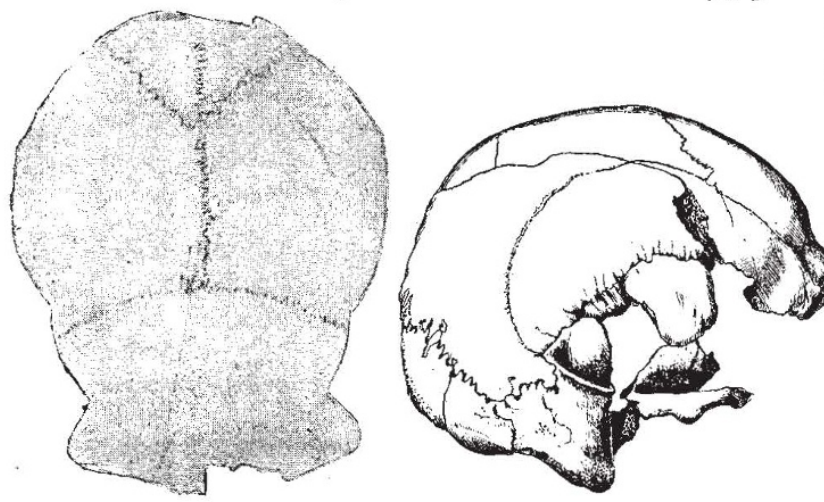

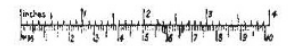

F1G. 2 .
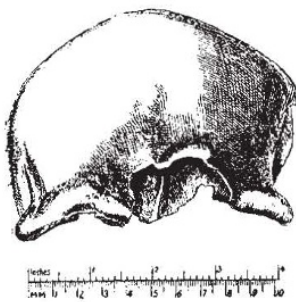

Fig. 4

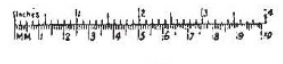

FiG. 3 .

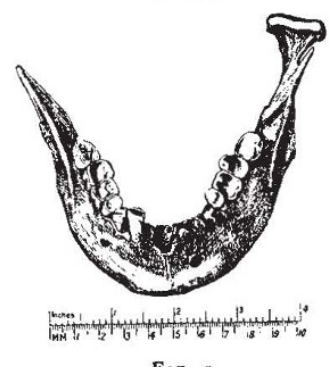

FIG. 5 haps a foreigner, who had lost his way and sunk down in the peaty swamp of the then undrained fens.

\section{T. McKenny Hughes.}

\section{THE INTERNATIONAL RADIUM STANDARD.}

THE committee formed at the Brussels Con1 gress of Radiology and Electricity in September, I9Io, for the purpose of fixing an international standard of radium, of which a full account appeared in NATURE of October 6, 1910, met in Paris from March 25-28. There were present Mme. Curie, MM. Debierne, Rutherford, Soddy, Hahn, Meyer, and Schweidler. MM. Geitel, Eve, and Boltwood were unable to attend. The main purpose of the meeting was to compare the standard prepared by Mme. Curie with others prepared by NO. 22 I 4 , VOL. 89$]$
Hönigschmid from the material in possession of the Académie des Sciences at Vienna, during the course of his new determination of the atomic weight of radium, referred to in Nature of March 2 I (p. 68). Mme. Curie's standard consisted of $21^{\circ} 99$ milligrams of radium chloride specially prepared by methods similar to those used by her for atomic weight determination, and sealed up in a thin glass tube with every precaution against error. The Vienna standards consisted of three tubes, containing respectively $10^{\circ} \mathrm{I}, 3 \mathrm{I}^{\circ} \mathrm{I}$, $40^{\circ} 43$ milligrams of radium chloride, which were sealed up in somewhat wider glass tubes, but of the same thickness of wall $\left(0^{\circ} 27 \mathrm{~mm}\right.$.) as the other, and were prepared by methods based on those devised by $T$. W. Richards for weighing hygroscopic substances.

It may be recalled that Hönigschmid found the value $225^{\circ} 95$ for the atomic weight of radium, which is $0^{\circ} 45$ lower than that found by Mme. Clirie. This is a difference of only $x$ part in 500 , and, considering the small amount of material, is probably not due to differences in the purity, especially as certain corrections, such as for the solubility of the silver chloride, were introduced into the calculation of the atomic weight from the later determinations. It was therefore of the greatest interest to compare directly these two sets of entirely independent standards. Mme. Curie was sufficiently recovered from her recent illness to take some part, both in the deliberations and measurements of the meeting. Prof. Rutherford was chosen as the president of the committee.

After a visit to Mme. Curie's laboratory in the rue Cuvier, the committee proceeded to the Sorbonne, where, in Prof. Lippmann's department, a room, uncontaminated by radium, had been set apart for the measurements. Here M. Debierne had set up an interesting installation, capable of comparing the $\gamma$-rays of the standards by two distinct methods. The first method is based on the well-known null-method, largely employed in Paris, but hardly anywhere else, involving the quartz piézo-électrique of Pierre Curie. The ionisation current due to the $\gamma$-rays of the preparation was balanced by the electricity generated by relieving the tension of a stretched quartz lamina, by gradually lifting a weight from the pan, the electrometer needle so being held to its zero and the time measured from the commencement to the end of the lifting of the weight. This requires practice, and the admirable skill of the French observers with the method was humorously illustrated by the attempts of some of the visitors to emulate them. The form of ionisation chamber adopted calls for special remark. The radium standard was laid on the centre of a large circular disc of lead, I cm. thick, which formed the upper plate of a condenser, the distance between the plates being small compared with their diameter. A potentional of 800 volts was used to ensure saturation.

The other method was that recently described at the Physical Society by Rutherford and Chadwick, and is also a null-method, the $\gamma$-ray ionisa- 